\title{
Possibilities of Industrial Heritage Reuse as Tourist Attractions - a Case Study of City of Zrenjanin (Vojvodina, Serbia)
}

\author{
Sonja ĆopićA ${ }^{A}$ Aleksandar Tumarić ${ }^{B}$ \\ Received: March 6, 2015 | Revised: May 8, 2015 | Accepted: June 5, 2015
}

\begin{abstract}
Industrial heritage tourism is a new form of tourism, which often involves reuse of abandoned industrial facilities for tourism purposes. Former industrial cities, affected by deindustrialization are looking for an oportunity to economically and socially revitalize themselves through this type of tourism, which is a general trend in developed countries. The subject of this paper is investigating possibilities for reuse of industrial heritage of the city of Zrenjanin in tourism purposes, which has been hit hard by deindustrialization due to wars, economic crisis and isolation during the last decade of the 2oth century. Abandoned factory complexes that serve no purpose now occupy city center, but have an important tourist potential. Some of these complexes include Zrenjanin brewery, the old city slaughterhouse and abandoned facilities of Šinvoz factory. Adaptation of these buildings into cultural, sports and shopping centers would instigate the developement of tourism in the city.
\end{abstract}

Key words: Industrial heritage, Zrenjanin, Vojvodina, industrial heritage tourism

\section{Introduction}

\section{The industrial heritage term and its significance for cities}

Industrial heritage is a specific type of human societies heritage that has emerged as a product of industrialization, i.e. as a side effect of deindustrialization of society, when certain facilities were abandoned (Beaudet, Lungren, 1996). Commonly used phrase when describing this heritage is "landscapes of nostalgia” (Halewood, Hannam, 2001). Industrial heritage includes objects that have lost their original function. This involves mines, infrastructure, machines, housing and public facilities designed for workers and others (TICCIH, 2003).

Industrial heritage has historical, social and architectural significance for the cities. Remembering the past and preserving the historical environment develops a strong sense of identity in local communi- ty (Castello, 2006). In recent decades, the value and potential of industrial heritage are used in urban renewal, especially in those cities that are affected by deindustrialization. These cities see an opportunity for economic gain and local development through the promotion of renewed industrial heritage (Cizler, 2011). In the beginning studying of industrial heritage was interesting only to "amateurs" and "enthusiasts". Gradually, its valorization, preservation and musealisation or repurposing have found their place in University courses, in the voluminous technical literature, and finally in the minds of citizens and political programs. The possibility of repurposing and reusing rudimentary buildings in the city center is in line with the stated principles of urban sustainability and "reasonable growth" (Dimitrijević-Marković, Sretenović 2008).

Reuse of industrial heritage has become heavily associated with attempts to create new urban land-

\footnotetext{
A University of Novi Sad, Faculty of Science, Department of Geography, Tourism and Hotel Management, Trg Dositeja Obradovića 3, 21000 Novi Sad, Serbia

B University of Novi Sad, Department of History, Faculty of Philosophy, Dr Zoran Đinđić 2, 21000 Novi Sad
} 
scapes that can encourage the development of the new economy of cities (Mengüşoğlu, Boyacıoğlu, 2013). This new economy is what Zukin (1995) calls "symbolic economy" based on finances, knowledge, media, entertainment, tourism and culture.

\section{Tourism as a reusing factor of industrial heritage space}

Space represents one of the most important resources of tourism as an economic activity. Space is limited as a resource, and tourism is constantly affecting its transformation (Maksin Mićić, 2008). Industrial heritage facilities are considered urban spaces, and tourism is a powerful tool for their reconstruction and preservation.

The development of tourism in these areas creates tourist sites which can be comprised of one building, a complex of buildings, or even a set of locations that make up several kilometers long tourist route. The effects of development of industrial heritage tourism are multiple and are reflected in raising awareness of the historical processes, increasing the inflow of tourists, strengthening local identity, improving the image of a city or a region, and thus attracting new investors, as well as adaptation and preparation of buildings for new purpose (Neumann, et al., 2012).

Harvey (1991) and Zukin (1995) have similar views on how culture and preservation of historical monuments can be important elements of postmodern or symbolic economy in which cultural strategies direct the production of commercialized urban spaces towards entertainment and tourism. According to Zukin "Sometimes it seems that all derelict industrial areas or waterfronts have been converted into sites for visual enjoyment, such as thematic areas selling seasonal products and cooking equipment, with restaurants, galleries and aquarium" (Zukin, 1995). The best examples of repurposed industrial facilities can be found in the UK and America. Britain has actually learned from America how to reuse its abandoned factories, warehouses, mills, market buildings and railway stations as an effective strategy for urban regeneration (Stratton, 2000; Maitland, 1997).

\section{Study area}

\section{Zrenjanin - general characteristics}

City of Zrenjanin is located in Banat region, Autonomous Province of Vojvodina, Serbia, at $20^{\circ} 23^{\prime}$ east longitude and $45^{\circ} 23^{\prime}$ north latitude, on the location where the channeled Begej river flows into the former bed of Tisza. It is the seat of the Central Banat District and occupying $8.3 \%$ of the territory of Vojvodina it is the second largest local government in the Republic of Serbia. The city is $75 \mathrm{~km}$ away from Belgrade, the capital of Serbia, and $50 \mathrm{~km}$ away from Novi Sad, the capital of Vojvodina, which is the same distance from Romanian border (which is a EU member). This position makes the city very important transitional center and potential resource in the north-south and eastwest direction. The city is located at the junction of the main roads that connect Serbia with Hungary and Romania (Internet 6). The city's population is 75,743 , while Zrenjanin municipality has 122,714 inhabitants (2011 census data).

\section{Industrial development and consequences of deindustrialization in city of Zrenjanin}

The beginnings of industrialization of Zrenjanin can be traced to the 18th century and the establishment of the brewery. Although the brewery is the oldest, synonym for industry in Zrenjanin was the Industrial and Agricultural Combine "Servo Mihalj". Combine was founded in 1953 and included a whole range of industrial and tourism facilities. Its members were: Agricultural Society "Zrenjanin" - which was engaged in farming and animal husbandry, fishing farm "Ečka" - part of the Combine since 1983, sugar factory, "Žitoprodukt" - a company that specialised in grain products, "Dijamant "- vegetable oil production,"BEK"- meat products, "Imlek" - production of milk and dairy products, "Jugoremedija" - pharmaceutical company, and "Luxol" - chemical industry. "Servo Mihalj" organized tours of Special nature reserve "Carska bara" and hunting tours (Odavić et al., 2011). Of all abovementioned factories only "Žitoprodukt" (partly owned by the Slovenian company "Don Don"), "Dijamant" (since 2005 part of the Croatian concern "Agrokor") and "Mlekoprodukt" (since 2004 owned by the French company "Bongrain") continue to operate.

Companies like "Sloga" (underwear production), "Udarnik" (sock factory) and "Proleter" (carpet factory) are bankrupt and have been out of business for years.

The cases of "Radijator" (production of radiators and boilers for central heating) and "Šinvoz" (repair of locomotives and railcars, and the production and repair of rail assemblies) are specific because they are still partly operational. Some of the buildings are no longer in use and can be considered industrial heritage. The old city slaughterhouse is also an example of industrial heritage, and it is largely abandoned.

Deindustrialization of Zrenjanin began in the 9os, and it was completed in early 21 st century. The reasons for the fall of industrial giants of Zrenjanin are numerous: political instability in the country, economic weakening due to war and isolation, poor management, abuse of privatizations and others. The consequences of 
deindustrialization reflected in a general deterioration of the city, in economic and social terms. The production was moved to new factory halls on the outskirts of the city, while the old industrial plants were neglected and abandoned, and now represent the basis for industrial heritage. These objects can be used for the development of industrial heritage tourism, which is a generator of economic growth, revitalization and preservation of local identities in developed countries.

\section{The possibility of transformation of industrial heritage of Zrenjanin into tourist attractions}

\section{Zrenjanin Beer Industry}

The brewery was founded in 1745 by the German artisan Sebastian Kreitceisen. It was named Veliki Bečkerek Brewery, which was at the time the name of Zrenjanin. In 1891 it was acquired by Lazar Dunđerski, famous landowner and industrialist in Vojvodina (Figure 1a). It remained the property of Dunđerski family until 1955, when it was nationalized. After WWII the name of the city was changed to Zrenjanin (after a national hero Žarko Zrenjanin), and subsequently the name of the brewery was changed to Zrenjanin Beer Industry (ZIP). In the 1962-1969 period the brewery was part of the Industrial and Agricultural Combine "Servo Mihalj". During the 70 s and 8os of the 2oth century, the brewery operated successfully, one of the indicators being the organization of the tradiotional "Beer Days" starting in 1985. Within the framework of the brewery operated vinegar and denaturated alcohol factories (Slavić, 1995). During the last decade of the 2oth century due to wars and isolation, there is a decline in production. The company went bankrupt in 2002, and despite the repeated attempts of privatization the investors were not interested (Figure 1b).

However, although the brewery is bankrupt, most of the equipment for production was preserved which can be used to restart production of beer or for adaptation of the brewery into a museum. The city of Berlin is a good example of transforming old breweries into art centers (Willner Brewery), restaurants (Bötzow Brewery) and microbreweries (Pfefferberg) visited by numerous tourists (Internet 2). These models of adaptation and transformation can be a guideline to Zrenjanin authorities in planning revitalization project of the old brewery, which could be offered to investors. Employees in tourism could design a tour of the factory grounds, which would include short course on the history of the brewery, beer tasting, accommodation and restaurant within the complex. Since the brewery is located along the shore of the Begej river, surrounding area could be cultivated and a new walkway built, which would make tourist offer more attractive.

\section{The abandoned facilities of "Šinvoz" factory}

The forerunner of today's factory was railway workshop founded in 1887. In the period from 1945 to the present "Šinvoz" factory has become the backbone of the development of Zrenjanin metal industry (Figure 2a) (Internet 3). However, old railway workshop facilities that are located close to the railway station are abandoned and derelict (Figure $2 \mathrm{~b}$ and $\mathrm{c}$ ) and represent unutilized potential.

Adaptation options for these facilities are numerous. Due to the large spatial capacity it would be most appropriate to adapt the buildings into a sports complex (which would allow organization of sporting events and generally encourage the development of sports tourism which is decrescent), a shopping center (which would stimulate the development of shopping tourism) or railway museum (which would contribute to education, preservation of local identity and development of cultural tourism and industrial heritage tourism). It is necessary to devise a master plan, propose it to the investors, and if implemented include it in the tourist offer of Zrenjanin. An example of good practice is the master plan for the reuse of the railway industry in Ipswich (Queensland, Australia). It includes the opening of a museum, space for exhibitions and concerts, festival organization, carnivals, restaurants and so on, in abandoned workshops, warehouses and auxiliary facilities. The long-term goal of the project is to create a rec-
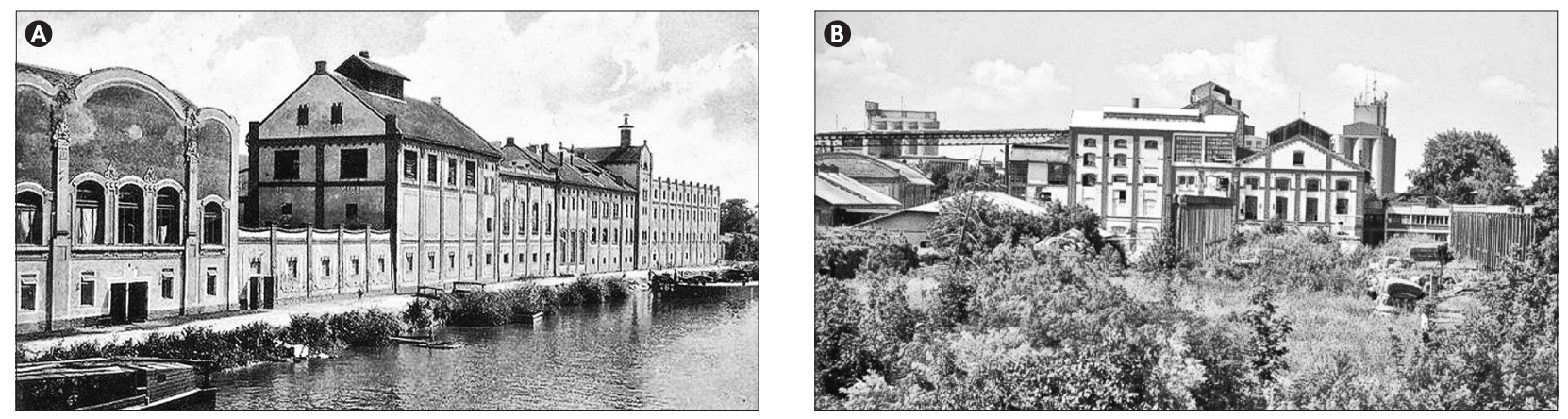

Figure 1. (A) Veliki Bečkerek Brewery at the beginning of the $20^{\text {th }}$ century (Source: Internet 3); (B) Zrenjanin Brewery present state (Source: Internet 1) 

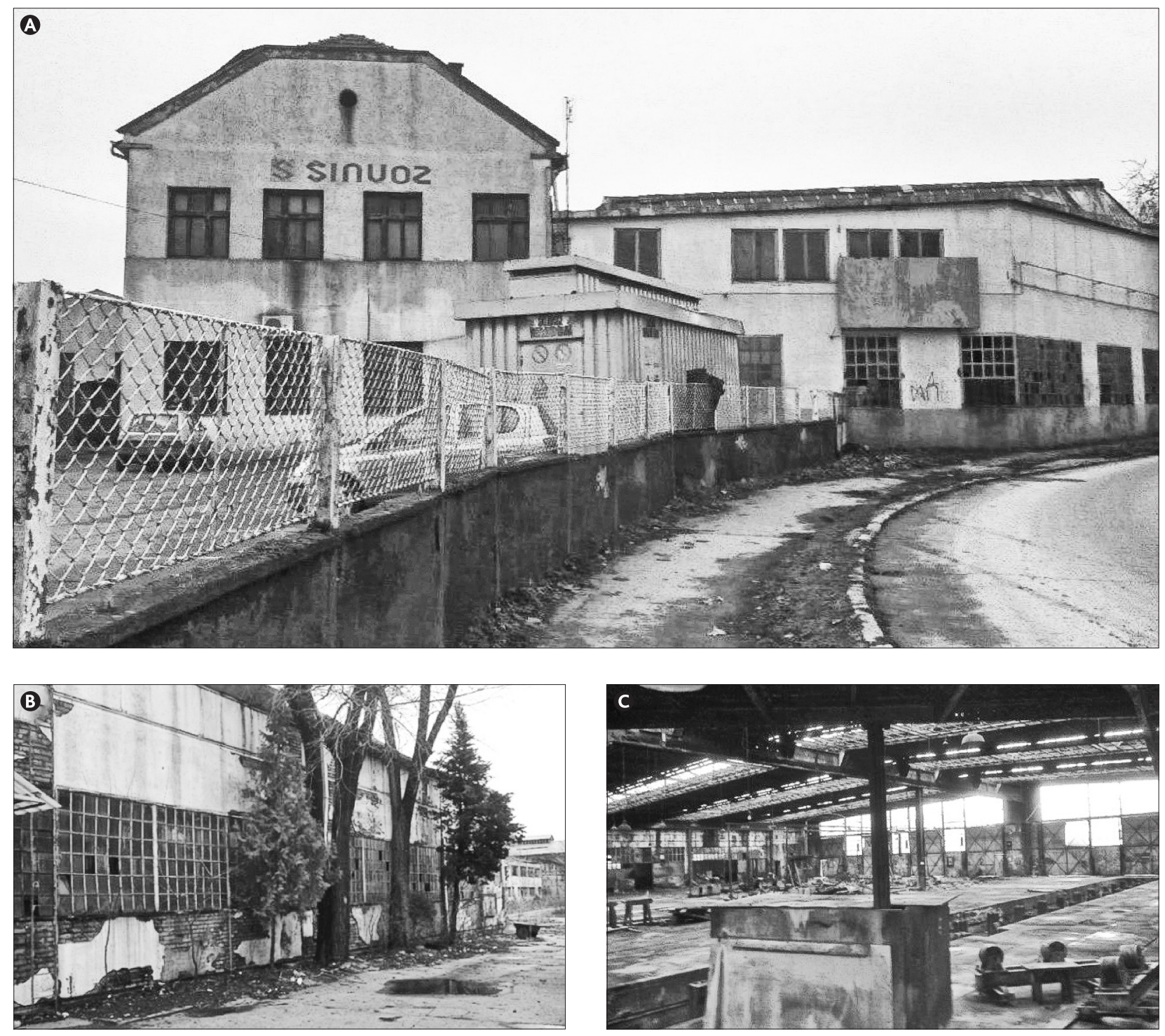

Figure 2. (A) "Šinvoz" factory (Photo by: S. Ćopić); (B) The exterior of abandoned facility of "Šinvoz" factory (Photo by: S. Ćopić); (C) The interior of abandoned facility of "Šinvoz" factory (Photo by: S. Ćopić)

ognizable tourist brand and the development of local and regional tourism (Internet 4).

\section{The old city slaughterhouse}

Complex of the old city slaughterhouse was designed by the architect Laszlo Szekely in 1909, and it was built

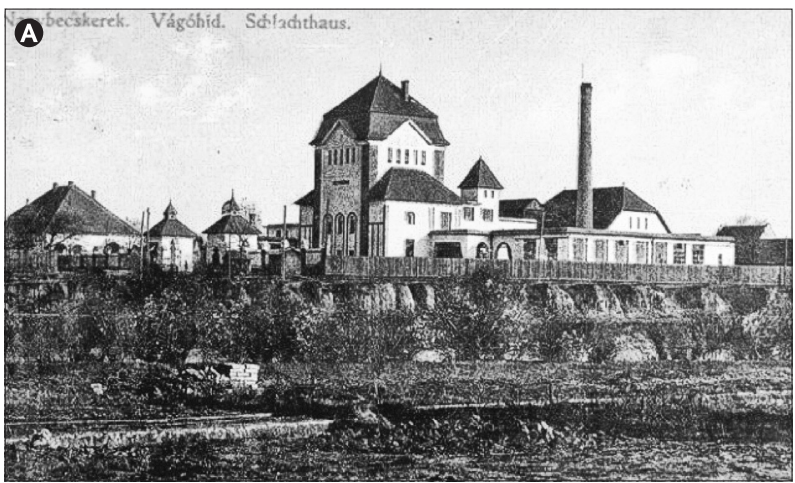

in 1913 along the left bank of the Begej river. Although it no longer serves its original purpose, it is one of the most beautiful sights in Zrenjanin in architectural terms (Figure 3) (Karavida, 2014).

A large part of the complex is now derelict, with exception of the former administration building which

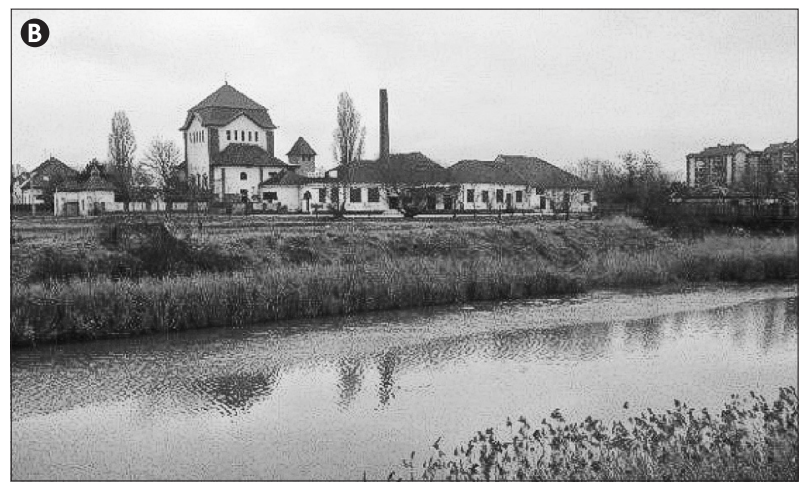

Figure 3. The old city slaughterhouse in 1913 (A) (Source: Internet 5); Present appearance of the complex (B) (Photo by: S. Ćopić) 


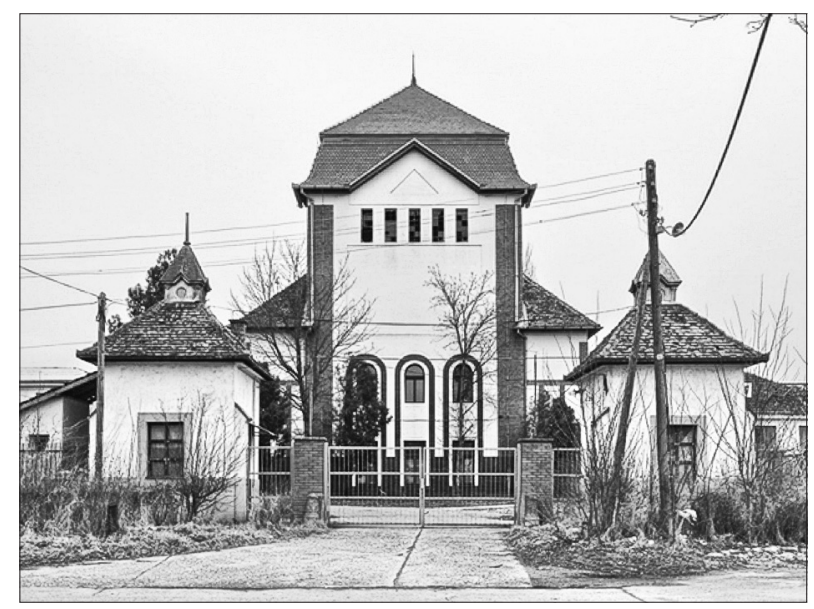

Figure 4. The tower at the entrance of the old city slaughterhouse complex

Source: Internet 6

was adapted into a kindergarten. The abandoned buildings of the complex inlclude halls, workshops, ice factory, as well as a massive tower which is visually dominant (Figure 4).

Tourism could in this case play an important role in the process of preservation and reuse of the abandoned buildings. Because of its architectural style it would be most appropriate to adapt the complex into cultural center and thereby incite the development of cultural tourism. The location of the old city slaughterhouse should be taken into account during the planning of this project, as it is located along the shore of the Begej river. Linking cultural tourism with various tourist activities on the river or on the waterfront can contribute to attractiveness of tourist offer.

\section{Conclusion}

Industrial heritage tourism is a form of tourism which is becoming more prevalent in developed countries. Namely, abandoned factories, industrial complexes, buildings, auxiliary facilities etc. get a new purpose and are often converted into tourist attractions. Cities affected by deindustrialization use this type of tourism for both economic and social revitalization.

As a result of wars, economic crisis, and isolation during the last decade of the 2oth century there had been a decline in industrial production in Serbia. This eventually led to complete collapse of local economies. One of the most powerful industrial centers in the country - Zrenjanin suffered the same fate. A series of abandoned factory complexes today defile the appearance of the city and represent unutilized potential. One possible solution to this problem is the conversion of abandoned industrial buildings into tourist attractions by using examples from around the world. In this paper, the emphasis is on abandoned buildings that have the most potential for tourist adaptation, primar- ily because of their location, architectural style, historical significance and spatial capacity. These are Zrenjanin brewery, the old city slaughterhouse and buildings of "Šinvoz" factory. Some of the ways of adaptation involve the transformation of the objects into cultural or sports centers, shopping malls or restaurants. The city must have a development strategy for tourism, especially for industrial heritage tourism. It is necessary to make a plan of transformation of these complexes and to include renewed complexes in the tourist offer. The implementation of such a project could affect not only the development of the city, but also the whole of Central Banat. If the project proved to be successful it could serve as an example of good practice for other cities in the country with unused industrial heritage.

\section{References}

Castello, L. 2006. City \& Time and Places: Bridging the Concept of Place to Urban Conservation Planning. City \& Time 2, 59-69.

Cizler, J. 2011.Reuse of derelict industrial sites: Opportunities for regeneration of industrial heritage in Pancevo, Serbia. Arhitektura i urbanizam 33, 75-80.

Dimitrijević-Marković, S., Sretenović, I. 2008. Possibilities and problems of revitalization of Belgrade sugar plant. Heritage IX, 267-276.

Harvey, D. 1991. The Condition of Postmodernity: An Enquiry into the Origins of Cultural Change, Blackwell, Cambridge, MA, 378.

Karavida, V. 2014. City slaughterhouse in Zrenjanin by architect Szekely Laszlo. Archival records for researching cultural monuments of Zrenjanin XXVII, Novi Sad, 65-73.

Maitland, R. 1997. Cities, Tourism and Mixed Uses, Reclaiming the City, Mized Use Development. ed. A. Coupland, E \& FN SPON, London, 92-5.

Maksin Mićić, M. 2007. Tourism and space. Singidunum University, Belgrade, 380 pp.

Mengüşoğlu, N., Boyacioğlu, E. 2013. Reuse Of Industrial Built Heritage For Residential Purposes In Manchester. METU JFA,30-1, 117-138.

Neumann, U., Trettin, L., Zakrzewski, G. 2012. Tourismus im Ruhrgebeit - Chances für kleine Unternehmen? RWI Materialen, Rheinisch-Westfälisches Institut für Wirtschaftsforschung, pp 88, 03 .

Odavić, M., Marjanac, D., Zotović, M., Radaković, D. 2011. Industrial and Agricultural Combine „Servo Mihalj“ Zrenjanin: 1953-1990. Historical archive: „Zrenjanin“, Zrenjanin, 197.

Slavić, Z. 1995. Two hundred and fifty years of Zrenjanin brewery. National city library “Žarko Zrenjanin", Zrenjanin, 202.

Stratton, M. 2000. Industrial Buildings, Conservation and Regeneration. E \& F N Spon, London, 11-188. 
TICCIH 2003. The Nizhny Tagil Charter for the Industrial Heritage. TICCIH XII International Congress, Nizhny Tagil.

Zukin, S. 1995. The Cultures of Cities. Blackwell, Cambridge, MA, 268.

$$
\propto
$$

Internet 1: www.novosti.rs/vesti/srbija.73.html:503885Zrenjanin-Ruine-cekaju-novi-sjaj
Internet 2: www.visitberlin.de/en/news-release/frombrewery-to-trendy-venue Internet 3: www.sinvoz.rs/onama/istorijat Internet 4: www.theworkshops.qm.qld.gov.au/ Site+Tools/Search?query=master+plan\&sitesearch-submit=\#.VPdkK_D91Ow

Internet 5: www.zrenjaninheritage.com/archives/1080 Internet 6: www.zrenjanin.rs/userfiles/file/Strategija\%2o odrzivog\%2orazvoja\%2oopstine\%2oZrenjanin.pdf 